\title{
COMPARATIVE IMPACT OF LOGISTICS PERFORMANCE INDEX, EASE OF DOING BUSINESS AND LOGISTICS COST ON ECONOMIC DEVELOPMENT: A FUZZY QCA ANALYSIS
}

\author{
Mohan SAINI(®i), Denisa HRUŠECKÁ (102 \\ Department of Industrial Engineering and Information System, \\ Faculty of Management and Economics, Tomas Bata University, Zlin, Czech Republic
}

Received 11 November 2020; accepted 07 May 2021

\begin{abstract}
This research papers aims to evaluate the impact of two major institutional indexes logistics performance index (LPI) and ease of doing business (EODB) along with logistics cost (LC) on the economic development (Gross domestic product - GDP per capita). The variables selected for the research study provides the comprehensive impact and forms the core of the economy for any country. Top seven economies of the world (China, France, Germany, India, Japan, United Kingdom and USA) along with Czech Republic, Singapore and Slovenia have been selected for this analysis. Mid-sized Economies of Czech Republic, Singapore, Slovenia have been selected for the regional balance of Asia and Europe and for cooperative results. A preliminary analysis of Pearson correlation analysis and detailed fuzzy qualitative comparative analysis have been opted for the study. The results illustrate that LPI is the core component for displaying the positive results on economic development. LC and EODB have displayed mixed results and will be studied in future research for identifying their impact on economic development. Future research will incorporate indexes such as global competitive index, innovation index for the evaluation of the combined impact on economic development.
\end{abstract}

Keywords: economic development, GDP, LPI, ease of doing business, logistics cost, fuzzy QCA.

JEL Classification: O40, O57.

\section{Introduction}

There are many important institutionalized indexes which rank and score the economies on the basis on their performances in various sectors. Two such indexes are logistics performance index (LPI) and ease of doing business (EODB). These indexes are evaluated by the World Bank to score and rank economies on the basis of their performance in facilitating setting up new businesses, EODB (World Bank, 2019) and their performance in logistics

\footnotetext{
${ }^{\star}$ Corresponding author. E-mail: saini@utb.cz
} 
sector, LPI (World Bank, 2018). Both these indexes play an important and pivotal role in the economic development of a country. EODB facilitates in setting up new business thus generating new supply and demand matrixes along with creating employment. Logistics sector facilitates the trade developments and promotes the movement of good across the regional, domestic and global market.

According to the estimates from the European Union and United states, proportion of logistics cost in percentage to GDP ranges from eight to ten percent. Economic growth of a country is considerably impacted by the logistics sector, involving various activities such as transportation, custom clearance, warehousing, freight movement (Mariano et al., 2017).

There have been multiple studies involving LPI in consideration to various global indicators to compare economic development, however there have been rarely any study to evaluate its impact along with a combined research to study the results. The LPI is a benchmarking index published by World Bank that compares logistics performance (Aldakhil et al., 2018). A research study conducted by Fernández-Serrano and Romero (2014) emphasized that EODB is associated with the development of economy supporting the factors that affect the setting up of business. In a study by Besley (2015), it was highlighted, that an attractive business environment is an important and major factor for the economic development.

The topic of economic development is extensively studied by the research academia, but there is only one single factor which is studied to evaluate the factor affecting economic development such as foreign development inflow (Adhikary, 2011; Bhavan et al., 2011), ease of availability of finances for small business and its relation to economic development (Abor \& Quartey, 2010) and importance of small business for economic growth (Naudé, 2010). The LPI in the research studies of Erkan (2014), Milenković et al. (2020) and EODB in the research study as performed by Corcoran and Gillanders (2015) and Morris and Aziz (2011) have been researched, however all studies have researched from a single variable perspective only.

The main objective of this research study is to identify the causal relationship between EODB, LPI, LC and economic development. Previous research studies have focused on identifying the relationship between one of these indexes in comparison to economic development, however this study aim to evaluate the combined effect of all three indexes on economic development along with logistics cost. The index of LPI and EODB forms the core of any economy and thus needs to be evaluated in comparison to LC for the combined effect on economic development.

The paper is structured as per the following details: The first section provided the theoretical background for logistics performance, ease of doing business and economic development in research studies. The second chapter presents research methodology of correlation analysis and fsQCA model along with its applicability and utility in this research. The third chapter illustrate results that includes the investigative relationship, data analysis and its empirical results. The discussion sections highlight the findings of fsQCA model on membership relation of variables in discussion. Last section presents the concluding results along with limitation and future research scope. 


\section{Theoretical background}

The research area of economic development in logistics and growth perspective has been extensively researched by research scholars. Various fields of logistics and supply chain such as logistics infrastructure (Wang et al., 2021), correlation between logistics and economics (Can et al., 2021), the distributive trade and economic growth (Mladenović et al., 2019), the technological advancements, development leading to economic development, (Lampropoulos et al., 2019) have been researched. Global institutions such as World Bank, evaluates and publishes indexes to rank economies on the international recognition parameters. Two such indexes are logistics performance index (LPI) and ease of doing business (EODB). These indexes are developed to rank the economies on the performance of logistics competency of any economy and ease of doing business evaluates the economy for its ability to attract investors in setting up a new business. As these two indexes relates to the core of an economy, thus it becomes imperative to identify their combined causal relationship on the economic development.

\subsection{Logistics performance index in research studies}

World Bank developed this index of evaluating logistics competency and performance of economies of every 2 years basis since 2007. LPI is a logistics competency benchmarking tool that ranks and scores economies based on the six parameters as detailed in Table 1. The six dimensions of evaluation consists of parameters such as customs, infrastructure, the competence in logistics, the timeliness in shipments, tracking and tracing and handling international shipments. All these components are critically evaluated for each economy for calculating LPI based upon theoretical and empirical research conducted by World Bank. This is evaluated by a questionnaire-based survey in which the respondent's rate on above-mentioned components on a five-point Likert scale (1 for very low and 5 for very high). Based on the responses, LPI index is calculated using a standard statistical technique of PCA (Principal component analysis). The output is weighted average of the scores (World Bank, 2014). Table 1 illustrates the definition of individual parameters of logistics performance index.

Table 1. Logistics performance index parameters (source: World Bank, 2018)

\begin{tabular}{|l|l|l|l|l|l|}
\hline \multicolumn{1}{|c|}{ Customs } & Infrastructure & $\begin{array}{c}\text { Logistics } \\
\text { competence }\end{array}$ & Timeliness & $\begin{array}{c}\text { Tracking and } \\
\text { Tracing }\end{array}$ & $\begin{array}{l}\text { International } \\
\text { shipments }\end{array}$ \\
\hline $\begin{array}{l}\text { Efficiency } \\
\text { of customs } \\
\text { and border } \\
\text { management } \\
\text { clearing. }\end{array}$ & $\begin{array}{l}\text { Quality of trade } \\
\text { and transport } \\
\text { infrastructure. }\end{array}$ & $\begin{array}{l}\text { Competence } \\
\text { and quality } \\
\text { of logistics } \\
\text { services. }\end{array}$ & $\begin{array}{l}\text { Shipments } \\
\text { delivering to } \\
\text { within expected } \\
\text { delivery times. }\end{array}$ & $\begin{array}{l}\text { Ability to } \\
\text { track and trace } \\
\text { consignments. }\end{array}$ & $\begin{array}{l}\text { Ease of } \\
\text { arranging } \\
\text { competitively } \\
\text { priced } \\
\text { shipments. }\end{array}$ \\
\hline
\end{tabular}

Several studies have researched on the importance of the LPI index across geographies to provide insight into the logistics competitiveness for various economies of the world such as Finland in a research study by Solakivi et al. (2009), the economy of Turkey for logistics competitiveness by Ekici et al. (2016), Brazil (Faria et al., 2015) and England (Khan \& Qianli, 
2017). In the similar lines, EODB index, is researched in a study by Fernández-Serrano and Romero (2014), Kalyvas and Mamatzakis (2014) and Pinheiro-Alves and Zambujal-Oliveira (2012), however these studies included only one type of index for the analysis purpose. LPI benchmarking tool is extensively researched in research academia as a performance indicator for global logistics. As per Dang and Yeo (2018) this tool is utilized both at regional and international level to analyze countries performance in logistics for the procedures and infrastructure. Author studied with a different strategy, comparing the impact of two different indexes along with logistics cost on economic development.

The LPI is calculated through a survey conducted at a global level of freight forwarding and logistics companies. The World Bank developed this tool for benchmarking purpose to calculate the logistics competitiveness of an economy (Arvis et al., 2018). LPI comprises of six core important parameters to rank economy on a global scale for logistics performance (Su \& Ke, 2017). A positive link was established between export production and economic growth in a research study by Ruzekova et al. (2020). It was concluded that smaller developing economies are dependent on export performance for the economic growth. There are also studies which relates the positive impact of logistics scenario in an economy with the trade openness. Another research study by Sriyana and Afandi (2020), it was concluded that trade openness and economic growth are positively related for a group for selected Asian economies.

The third variable in this study which is logistics cost is an important part of the research study. For international competitiveness, countries need to maintain low logistics cost for outperforming on a global scale (Devlin \& Yee, 2005). Gross domestic products impact on price level was found out to be positive along with its strengthening role in defining countries competitiveness (Milenković et al., 2020). Another research study evaluated the importance of LPI parameters in relation with the international trade. This was research for the trading emerging economies and was analyzed and examined through a gravity model. This resulted in establishing that the respective components of LPI parameters have positive impact on international trade, Martí et al. (2014). In another study, a hierarchical regression analysis was adopted to understand the mediating impact of LPI in global competitive index (GCI) and GDP. Both these indexes are significant for defining logistics competency (Civelek et al., 2015).

\subsection{Ease of doing business in research studies}

The ease of doing business score evaluates the regulatory performance of economies over a period of time. It is helpful is assisting economies in understanding the gap of respective economy from the best across all economies in the doing business sample (World Bank, 2020).

The main objective of ease of doing business index and score is to help in assessing the absolute level of the performance of regulatory. This is performed by benchmarking individual economies against the best economy in regulatory performance which is evaluated based on each of the indicators of all the economies assesses in ease of doing business. This is a similar indexing tool such as LPI and is evaluated across twelve parameters such as starting 
a business, dealing with construction permits, getting electricity, registering a property, credit availability, protecting minority investors, tax payments, trading across borders, enforcing contracts, resoling insolvency, employing workers and contracting with government (World Bank, 2020).

The ease of doing business and similar rankings such as logistics performance index studies various different and complex aspects of business environment and economy. Therefore, it becomes imperative to conduct a study for evaluating its impact of economic development with multidimensional impact. The research studies analysis is shifting the focus of secondary research of indicators to the ease of doing business index (World Bank, 2019). Various other studies (Morris \& Aziz, 2011) identified the FDI flow and business climate relationship by correlating EODB with FDI.

Ani (2015) researched on the explanation of the effect of EODB to the economic development and growth for few selected economies of Asia. In the comparison with GDP, it was concluded that Singapore had the maximum positive indicators linked to the economic growth. Total 29 economies across the regions of East Asia, South East Asia and South Asia were compared. Though Singapore scored well on the maximum positive indicators, China had the highest economic growth based upon various parameters of the EODB. Rogge and Archer (2021) recomputed EODB by exploring a benefit of doubt weighted method. They evaluated the changes in version from 2010-2019 and concluded considerable changes in EODB between and within various regions. They clustered the regions and evaluated the performance of EODB across different regions. The ease of doing business has also been studied in various other research literature however these research study emphasizes on an individual single variable only (Corcoran \& Gillanders, 2015). Tvaronavičienè and Ginevičius (2003) studied alternative approached on the impact of foreign direct investment through globalization on the economic development.

Ghosh et al. (2019) developed a novel index sustainable development goal (SDG) benchmarking various other indexes such as ease of doing, FDI inflows in states for 23 states of India and found SDG to be significant with EODB in econometric analysis.

This research study evaluates the influence of multiple competitive indicators LPI and EODB along with logistics cost on the economic development exploring fuzzy causal relationship having both positive and negative relations. The main purpose of this study is to understand the impact of LPI, EODB along with LC for a significant role on impacting economic development.

Most of the researches have focused on comparing one index or single independent variable with economic growth and development. There has been rarely any study which evaluated the combination of multiple indexes along with key mediator or independent variable such as logistics cost on the economic development. This research study contributed to the literature by analyzing the combined impact and utilizing fuzzy sets qualitative analysis along with correlation to identify the configurations which impact the economic development. This paper also contributes to literature by presenting results of evaluating two global indexes along with logistics cost on economic development. 


\section{Research methodology}

This research paper adopts mixed analysis methodology of Pearson correlation to identify the preliminary relationship between variables LPI, EODB and LC on economic development. Subsequently fuzzy set qualitative comparative analysis was adopted for analyzing the causal combination relationship. The secondary data from the World Bank for GDP per capita, logistics performance index and logistics cost for the year 2018 is considered for the analysis purpose. All the three-index data is evaluated by the World Bank for ranking the economies on respective parameters on economic performance, logistics performance and ease of doing business. LC data is considered in terms of GDP per capita for the purpose of analysis, GDP, LPI and EODB data is considered as the absolute score extracted from World Bank data for the year 2018. Major economies of the world, that is China, Czech Republic, France, Germany, India, Japan, Singapore, Slovenia, United Kingdom and USA have been considered for identifying the causal configurations. The selection is based upon the non-probability judgmental sampling on the basis of the performance in world bank index and the regional balance. As these indexes forms the core of any economy, thus it is imperative to study the impact of LPI, LC and EODB on economic development. The initial and primary relation between the four researched variables was evaluated through the Pearson's correlation coefficient. Subsequent analysis was performed with fsQCA methodology identifies causal configurations that results in the higher values of GDP per capita were identified (Table 2).

Table 2. Methodology (source: compiled by authors)

\begin{tabular}{|l|l|}
\hline $\begin{array}{l}\text { Correlation } \\
\text { coefficient }\end{array}$ & $\begin{array}{l}\text { Correlation analysis is to measure the statistical relationships between two samples } \\
\text { or variables. }\end{array}$ \\
\hline fsQCA & $\begin{array}{l}\text { Fuzzy set QCA (qualitative comparative analysis fsQCA) is one the widest and } \\
\text { emerging research technique within the management field (Forkmann et al., 2017). }\end{array}$ \\
\hline
\end{tabular}

A detailed process of fuzzy fsQCA process is illustrated in Figure 1. The process from data inputting in csv (comma separated values) to calibration, creation of fuzzy scores, truth table generation along with standard analysis for the formation of necessary causal configurations is pursued in this process.

The fuzzy set qualitative comparative analysis technique was first introduced by Ragin (2000) for research purpose. This technique is different from correlation and regression in ways such as it establishes to calculate the associated causal effect rather regression which identified the single effect relationship between dependent and independent variables (Skarmeas et al., 2014). In the analysis of regression, multiple independent variables are evaluated for their significant effect on dependent variables. These independent variables are added to regression computation due to low collinearity and thus result may change from significant to non-significant as illustrated in a research study by Woodside (2013). However, in the case of fsQCA, asymmetry equation and causal complexity results in multiple paths that lead to same outcome result with different combinations (Elliot, 2013). To establish a relationship between dependent and independent variables for smaller subset regression analysis is not sufficing the purpose, thus technique such as fsQCA becomes useful (Liu et al., 2017). 


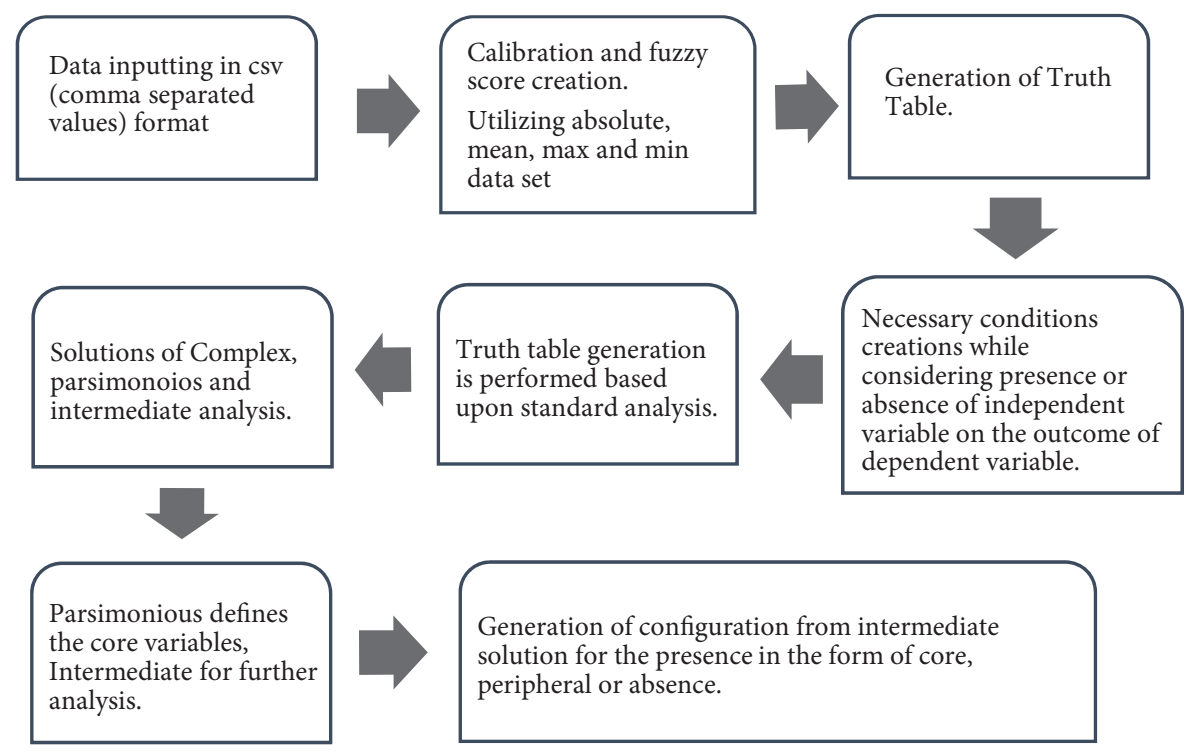

Figure 1. fsQCA data analysis process (compiled by authors)

\section{Results}

The results have been illustrated by comparing correlation analysis (Figure 2) along with fsQCA (Table 7). Firstly, to establish and analyse the initial findings of data trend, a correlation analysis was performed to identify the relationship between LPI, LC, EODB and economic development. To perform this, the normal distribution of data in the form of KS test was performed and it is identified that economic development data is normally distributed with the significance values. The detailed correlation analysis illustrates that there is a strong positive correlation between economic development and LPI (0.77) and EODB (0.86), however there is a negative correlation between GDP and LC (-0.84). An additional analysis to identify the correlation between LPI and LC also illustrates that there is a strong negative correlation between them $(-0.76)$.

In the subsequent steps of analysis, as correlation analysis is not the causation hence, the fsQCA analysis is performed to identify the causal configurations of selected variables that results in higher or lower values of outcome variables (GDP per capita) for the presence or absence of input variables (LPI, LC and EODB)

\subsection{Correlation analysis}

Normal distribution of the dependent variable GDP was identified through one sample KS test and it was identified that GDP data is approximately normally distributed. Skewness and Kurtosis are a little skewed and kurtotic for dependent variable GDP, but it does not differ significantly from normality (Table 3). 
Table 3. Test of normality (source: compiled by authors)

\begin{tabular}{|c|c|c|c|c|c|c|}
\hline \multicolumn{8}{|c|}{ Tests of Normality $^{*}$ Kolmogorov-Smirnov $^{\mathrm{a}}$} & \multicolumn{3}{c|}{ Shapiro-Wilk } \\
\hline \multirow{3}{*}{ GDP } & \multicolumn{3}{|c|}{ Sig. } \\
\cline { 2 - 8 } & Statistic & $\mathrm{df}$ & Sig. & Statistic & $\mathrm{df}$ & Sig. \\
\cline { 2 - 7 } & .157 & 10 & $.200^{*}$ & .961 & 10 & .792 \\
\hline
\end{tabular}

Note: ${ }^{*}$ This is a lower bound of the true significance/Lilliefors Significance Correction.

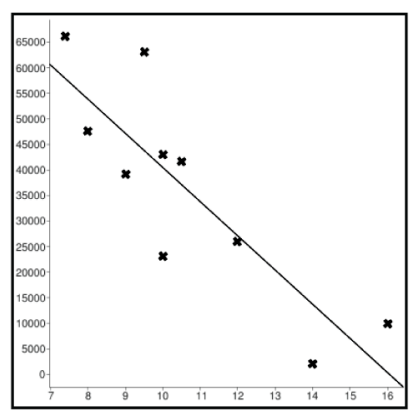

GDP and LC

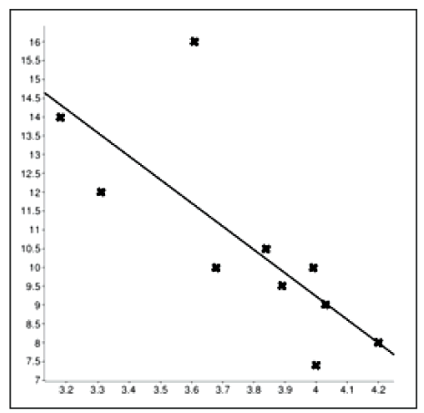

LPI and LC

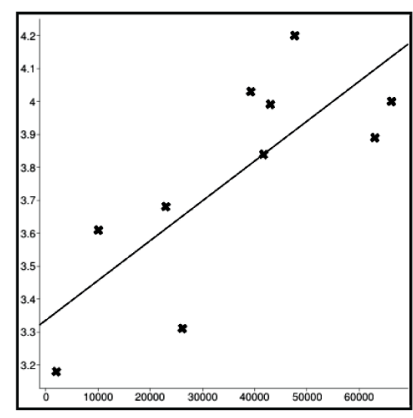

GDP and LPI

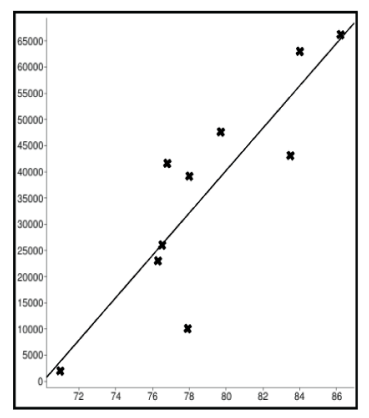

GDP and EODB

Correlation coefficient was used to determine and summarise the strength and direction (negative or positive) of a relationship between GDP per capita and LC, LPI and EODB. It was identified that GDP is positively correlated with LPI $(0.77)$ and EODB (0.86) whereas negatively correlated with LC $(-0.84)$. It is also to be observed that there is a negative correlation between LC and LPI (-0.76).

Figure 2. Correlation comparison between GDP, LPI, LC and EODB (source: compiled by authors)

\section{2. fsQCA descriptive data analysis and calibration}

fsQCA (Fuzzy set qualitative comparative analysis) is a research methodology to identify and combine independent variables effect on dependent variable utilizing causal recipes. The data analysis method of fuzzy fsQCA is extensively adopted by the researchers in the management science (Kraus et al., 2018). Fuzzy computation starts with inputting data in a csv (comma separated values) file in fsQCA 3.0 software.

Data is converted to fuzzy scores (Table 4) by computing with calibrated scores (Table 5). These scores are calculated using maximum, mean and minimum scores along with absolute data. Fuzzy scores range from 0 to 1 (Table 4).

This process calculates scores based on a rating and thus generating the truth table. This truth table along with necessary conditions illustrating the membership relation and its effect 
for higher values of outcome variable. Multiple configurations are formed by the associated results leading to the higher or lower values of GDP per capita (Schneider et al., 2010). These configurations represent solution such as complex solution, parsimonious and intermediate. Parsimonious represent the core membership results and intermediate are utilized for further analysis in management science. These outcomes result in the form of causal configurations rather evaluating the correlation between researched variables (Kourouthanassis et al., 2017). Research scholars from the various fields especially management and economics have emphasized on the critical relation of such causal configurational analysis for research purpose (Fiss, 2011).

Table 4. Computation of fuzzy scores (source: compiled by authors)

\begin{tabular}{|l|c|c|c|c|}
\hline \multicolumn{1}{|c|}{ Country } & fzGDP & fzLPI & fzEODB & fzLC \\
\hline China & 0.09 & 0.28 & 0.4 & 0.95 \\
\hline Czech Republic & 0.24 & 0.35 & 0.27 & 0.3 \\
\hline France & 0.63 & 0.57 & 0.3 & 0.64 \\
\hline Germany & 0.76 & 0.95 & 0.57 & 0.13 \\
\hline India & 0.05 & 0.04 & 0.05 & 0.82 \\
\hline Japan & 0.57 & 0.85 & 0.41 & 0.13 \\
\hline Singapore & 0.95 & 0.82 & 0.95 & 0.05 \\
\hline Slovenia & 0.29 & 0.08 & 0.28 & 0.3 \\
\hline UK & 0.67 & 0.81 & 0.87 & 0.3 \\
\hline USA & 0.94 & 0.66 & 0.89 & 0.13 \\
\hline
\end{tabular}

Notes: fz - fuzzy score; fzLPI - fuzzy score score logistics performance index; fzLC - fuzzy score logistics cost; fzGDP - fuzzy score GDP per capita; fzEODB - fuzzy score ease of doing business.

Table 5. Descriptive statistics (source: compiled by authors)

\begin{tabular}{|l|c|c|c|c|c|c|}
\hline & Mean & Standard Deviation & Min. & Max. & $\mathrm{N}$ & Calibration \\
\hline GDP & 36174.2 & 20992.5 & 2005.9 & 66188.8 & 10.0 & $(66188.8,36174.22,2005.9)$ \\
\hline LPI & 3.8 & 0.3 & 3.2 & 4.2 & 10.0 & $(4.2,3.773,3.18)$ \\
\hline EODB & 79.0 & 4.5 & 71.0 & 86.2 & 10.0 & $(86.2,78.99,71)$ \\
\hline LC & 10.8 & 2.8 & 8.0 & 17.0 & 10.0 & $(17,10.8,8)$ \\
\hline
\end{tabular}

The main aim of this fuzzy approach is to evaluate and identify the impact of mutually related configuration of LPI, EODB and LC on higher values of GDP per capita. Table 6 depicts the impact of individual independent variables under study LPI, LC and EODB presence or absence $(\sim)$ on the higher values of GDP per capita. The scores of consistency and coverage for each independent variable presence or absence are computed. Multiple research studies in management and economics have considered a consistency value of more than 0.9 as necessary, however few have also considered 0.8 to be necessary as well necessary (Schneider et al., 2010). 
Higher values of presence of EODB and LPI results in higher values of GDP per capita in necessary conditions coverage. Importance of such an analysis is to derive on the conditions which are always necessary for the presence or absence for higher values of outcome variable. The score ranges from 0.38 to 0.92 for the consistency of causal factors. There are three necessary conditions for which consistency is higher than 0.80. Presence of EODB and LPI along with absence of LC contributed to higher values of GDP per capita which is in sync with the correlation results.

Table 6. Necessary conditions (source: compiled by authors)

\begin{tabular}{|c|c|c|}
\hline Dependent variable: fzGDP & Consistency & Coverage \\
\hline fzLC & 0.393064 & 0.544000 \\
\hline$\sim$ fzLC & $0.926782^{\star}$ & 0.769600 \\
\hline fzEODB & $0.857418^{\star}$ & 0.891784 \\
\hline$\sim$ fzEODB & 0.499036 & 0.516966 \\
\hline fzLPI & $0.867052^{\star}$ & 0.831793 \\
\hline$\sim$ fzLPI & 0.387283 & 0.437908 \\
\hline
\end{tabular}

Notes: Symbol “ " indicates absence of condition; Meets 0.80 consistency benchmark for usually necessary conditions.

Table 7 displays the outcome of configurations that represents the higher values of GDP (fzGDP) in the intermediate solution. Necessary conditions analysis for the intermediate solution is crucial for the detailed understanding of the configurations. Table 6 shows that all conditions are not necessary for the higher values of GDP per capita.

Table 7. Intermediate solution (source: compiled by authors)

\begin{tabular}{|l|c|c|}
\hline \multicolumn{1}{|c|}{ Causal Configuration } & 1 & 2 \\
\hline fzLC & $\varnothing$ & $\mathrm{X}$ \\
\hline fzEODB & $\mathrm{x}$ & $\varnothing$ \\
\hline fzLPI & 0.818882 & 0.445087 \\
\hline Raw Coverage & 0.421965 & 0.0481696 \\
\hline Unique Coverage & 0.889121 & 0.878327 \\
\hline Consistency & \multicolumn{2}{|c|}{0.867052} \\
\hline Overall Solution coverage & \multicolumn{2}{|c|}{0.862069} \\
\hline Overall Solution consistency & \multicolumn{2}{|c|}{} \\
\hline
\end{tabular}

Notes: • indicates the presence of a condition; $\varnothing$ indicates the absence of a condition; $\bullet / \varnothing$ indicates core conditions; $\bullet / \varnothing$ indicates peripheral conditions; $\mathrm{x}$ indicates no contribution to configuration.

In Table 7, causal configuration 1 shows that membership degree of absence of LC and presence of LPI results in higher values of GDP per capita. In causal configuration 2, it is identified that absence of EODB and presence of LPI contributes for higher values of GDP per capita. Variable LPI is identified in the parsimonious solutions which reflects the presence or absence as a core variable impacting the outcome variable for higher values. 
It is significant to be observed that all the parameters EODB, LPI and LC combined are not the core parameters which impact the higher values of GDP per capita. LC has a negative inverse effect on the economic development in one of configurations, whereas LPI is the core variable as it is present in parsimonious solution and its presence in both the configurations contributes to the higher values of GDP per capita. The condition of negative relation of LC displays that it is an important variable of the study and should also be part of LPI while ranking economies for their logistics performance.

\section{Discussion}

The results displayed in Table 7 and Table 8, that results are significant to illustrate the combined effect of LC, LPI and EODB on the economic development. The results of correlation analysis have displayed the positive relationship between logistics performance index, ease of doing business and economic development, however negative relationship between logistics costs and economic development. The results evaluated by fsQCA illustrates the importance of reduction in logistics cost with a negative coefficient and absent condition results for the higher values of GDP per capita. LPI is present as a core membership variable in fsQCA and has a positive correlation for the higher values of GDP per capita. The previous researches have focussed on understanding impact of export production, trade openness Sriyana and Afandi (2020), global competency (Civelek et al., 2015), environmental factors, green logistics by comparing with economic development and growth (Ruzekova et al., 2020; Milenković et al., 2020). This research study has contributed to the literature by comparing the causal impact of LC and EODB with LPI on economic development. Logistics costs is an important parameter of evaluating the logistics efficiency of an economy A research study by Rantasila and Ojala (2015) identified the national level logistics costs into three categories: absolute costs, percentage of sales and percentage of GDP. As this research study has considered two of the macroeconomics perspectives of study that is economic development and ease of doing business along with logistics performance index, the logistics cost is utilized along with the method of novel fuzzy qualitative analysis, fsQCA to perform the causal analysis.

On the basis of overall analysis utilizing comparative results, we can conclude that LPI is the core membership solution for the higher values of GDP per capita with the inverse relationship of LC. However, EODB has shown mixed outputs from Pearsons correlation and fsQCA study. Future research should extend this study for larger number of countries in finding the relevance of ease of doing business effect on the economic development basis the combinational effect with LPI and LC.

It is also understood, that with reduction in LC in percentage to GDP is a sign of reduction in cost of goods and higher purchasing power and thus contributing to growth in GDP per capita. These results have major implications as with complex market and supply chain the combined effect of various factors is to be evaluated for the higher values of GDP per capita. These global indexes which ranks economies for their overall performance in logistics sector and attracting new business for investments needs to be evaluated for the combined effect on GDP per capita. With the improvement and advancement in business set up, there is a much impetus required for setting up advance logistics infrastructure. Table 8 illustrates 
the combined comparative results of research study and their combined impact on higher values of GDP per capita.

Table 8. Comparison of correlation and fsQCA results (source: compiled by authors)

\begin{tabular}{|l|l|l|l|l|}
\hline \multirow{2}{*}{$\begin{array}{c}\text { Outcome } \\
\text { Variable }\end{array}$} & \multirow{2}{*}{$\begin{array}{c}\text { Variables } \\
\text { (Test) }\end{array}$} & \multirow{2}{*}{ Correlation } & \multicolumn{2}{|c|}{ fsQCA } \\
\cline { 4 - 5 } & & & \multicolumn{1}{|c|}{ fsQCA Config I } & \multicolumn{1}{c|}{ fsQCA config II } \\
\hline \multirow{3}{*}{ GDP } & LC & Negative & Absent peripheral solution & No relation \\
\cline { 2 - 5 } & LPI & Positive & Present core solution & Present core solution \\
\cline { 2 - 5 } & EODB & Positive & No relation & Absent peripheral solution \\
\hline
\end{tabular}

\section{Conclusions}

This research study focussed on analysing the comparative impact of logistics performance index (LPI), ease of doing business index (EODB) and logistics cost (LC) on the economic development. The study is conducted considering the major economics across the Asia, Europe, UK and USA. The secondary data of World Bank for LPI, EODB and LC was extracted for the year 2018 and compared for analysis adopting mixed analysis approach of correlation and qualitative comparative method fsQCA.

The results have illustrated that the efficiency in logistics competency resulting with reduction of logistics costs correlates with the overall development level of the economy. Based on the fsQCA analysis along with correlation analysis, LPI is the identified as core solution resulting in the higher values of GDP per capita however LC and EODB have been affecting with their absence at a peripheral level of causal configuration.

The initial result of correlation analysis illustrates that there is an inverse relation of logistics cost and core presence of LPI in the identified causal configurations for the output of fzGDP. Previous researches have focussed on the comparison of single factor impact on the economic development such as global competitive index, environmental related index, infrastructure weighted index, income and geographic aspect of sustainability, however this research study has considered the core performing indexes for any economic which are LPI, EODB along with LC to identify and understand the comparative impact. This study has identified two causal configurations which are resulting in the higher values of GDP per capita in relation to the LC, LPI and EODB. This establishes an important orientation in the addition of logistics cost in the LPI index evaluation of ranking the economies.

Altogether, the main theoretical contribution of this study is in better understanding of comparative impact of core performing indexes to economic development of a country. It contributes to scientific knowledge with regard to the role of logistics in GDP per capita development. The main findings have also practical impact to individual economies in supporting such activities that can positively influence LPI or LC and thereby increase its economic performance. Subsequent research activities can also influence future legislative regulations in the field of logistics. As Virglerová et al. (2020) highlight, the role of stability of legislative context is essential for favourable business environment and it goes double for logistics activities. 
In summary, better infrastructure and policies for improving logistics network to enable reduced logistics cost and improvement in LPI factors results in the higher values of GDP per capita. This study has limitation of reflecting the research considering major economics of the world. It is therefore required to be study for other regions and also an inter region study for results insight. On the other hand, a combined effect of all major indexes like global competitive index, innovation index should be included for having an overall impact on GDP per capita.

\section{Author contributions}

MS and DH conceived the study and were responsible for the design and conceptualization. MS extracted the data and designed the methodology along with data analysis. DH was responsible for data interpretation and structing the paper in the format and design proofing.

\section{Disclosure statement}

Authors No potential conflict of interest was reported by the author(s).

\section{Funding}

The authors are thankful to the Internal Grant Agency of FaME TBU in Zlín No. IGA/ FaME/2021/002 for the financial support to carry out this research.

\section{References}

Abor, J., \& Quartey, P. (2010). Issues in SME development in Ghana and South Africa. International Research Journal of Finance and Economics, 39, 218-228. http://www.internationalresearchjournaloffinanceandeconomics.com/ISSUES/irjfe_39_15.pdf

Adhikary, B. K. (2011). FDI, trade openness, capital formation, and economic growth in Bangladesh: A linkage analysis. International Journal of Business and Management, 6(1), 16-28. https://doi.org/10.5539/ijbm.v6n1p16

Aldakhil, A. M., Nassani, A. A., Awan, U., Abro, M. M. Q., \& Zaman, K. (2018). Determinants of green logistics in BRICS countries: an integrated supply chain model for green business. Journal of Cleaner Production, 195, 861-868. https://doi.org/10.1016/j.jclepro.2018.05.248

Ani, T. G. (2015). Effect of ease of doing business to economic growth among selected countries in Asia. Asia Pacific Journal of Multidisciplinary Research, 3(5), 139-145. http://www.apjmr.com/wp-content/uploads/2016/02/APJMR-2015-3.5.2.19.pdf

Arvis, J., Wiederer, C., Shepherd, B., Raj, A., Dairabayeva, K., \& Kiiski, T. (2018). Con-necting to compete 2018: Trade logistics in the global economy. The International Bank for Reconstruction and Development/The World Bank. https://doi.org/10.1596/29971

Besley, T. (2015). Law, regulation, and the business climate: The nature and influence of the World Bank Doing Business project. Journal of Economic Perspectives, 29(3), 99-120. https://doi.org/10.1257/jep.29.3.99

Bhavan, T., Xu, C., \& Zhong, C. (2011). Determinants and growth effect of FDI in south Asian economies:Evidence from a panel data analysis. International Business Research, 10(1), 23-30. https://doi.org/10.5539/ibr.v4n1p43 
Can, B. E., Dinç, D. T., \& Gökmen, A. (2021). The issue of logistics and its correlation to economic growth in Turkey: An empirical application. International Journal of Applied Logistics (IJAL), 11(1), 66-80. https://doi.org/10.4018/IJAL.2021010105

Civelek, M. E., Uca, N., \& Çemberci, M. (2015). The mediator effect of logistics performance index on the relation between global competitiveness index and gross domestic product. European Scientific Journal, 11(13), 368-375.

Corcoran, A., \& Gillanders, R. (2015). Foreign direct investment and the ease of doing business. Review of World Economics, 151(1), 103-126. https://doi.org/10.1007/s10290-014-0194-5

Dang, V. L., \& Yeo, G. T. (2018). Weighing the key factors to improve Vietnam's logistics system. The Asian Journal of Shipping and Logistics, 34(4), 308-316. https://doi.org/10.1016/j.ajsl.2018.12.004

Devlin, J., \& Yee, P. (2005). Trade logistics in developing countries: The case of the Middle East and North Africa. The World Economy, 28, 435-456. https://doi.org/10.1111/j.1467-9701.2005.00620.x

Ekici, Ş. Ö., Kabak, Ö., \& Ülengin, F. (2016). Linking to compete: Logistics and global competitiveness interaction. Transport Policy, 48, 117-128. https://doi.org/10.1016/j.tranpol.2016.01.015

Elliot, T. (2013). Fuzzy Set qualitative comparative analysis. Research Notes: Statistics Group, UCI. https://www.socsci.uci.edu/ sgsa/docs/fsQCA_thomas_elliot.pdf

Erkan, B. (2014). The importance and determinants of logistics performance of selected countries. Journal of Emerging Issues in Economics, Finance and Banking, 3(6), 1237-1254. http://globalbizresearch.org/ economics/images/files/86028_JEIEFB_Birol\%20ERKAN.pdf

Faria, R. N. D., Souza, C. S. D., \& Vieira, J. G. V. (2015). Evaluation of logistic performance indexes of brazil in the international trade. RAM. Revista de Administração Mackenzie, 16(1), 213-235. https://doi.org/10.1590/1678-69712015/administracao.v16n1p213-235

Fernández-Serrano, J., \& Romero, I. (2014). About the interactive influence of culture and regulatory barriers on entrepreneurial activity. International Entrepreneurship and Management Journal, 10(4), 781-802. https://doi.org/10.1007/s11365-014-0296-5

Fiss, P. C. (2011). Building better causal theories: A fuzzy set approach to typologies in organization research. Academy of Management Journal, 54(2), 393-420. https://doi.org/10.5465/amj.2011.60263120

Forkmann, S., Henneberg, S. C., Witell, L., \& Kindström, D. (2017). Driver configurations for successful service infusion. Journal of Service Research, 20(3), 275-291. https://doi.org/10.1177/1094670517706160

Ghosh, N., Saha, R., \& Bhowmick, S. (2019). SDG index and ease of doing business in India: A subnational study. https://www.orfonline.org/research/sdg-index-and-ease-of-doing-business-in-indiaa-sub-national-study-52066/

Kalyvas, A. N., \& Mamatzakis, E. (2014). Does business regulation matter for banks in the European Union? Journal of International Financial Markets, Institutions and Money, 32(1), 278-324. https://doi.org/10.1016/j.intfin.2014.06.007

Khan, S. A. R., \& Qianli, D. (2017). Does national scale economic and environmental indicators spur logistics performance? Evidence from UK. Environmental Science and Pollution Research, 24(34), 26692-26705. https://doi.org/10.1007/s11356-017-0222-9

Kourouthanassis, P. E., Mikalef, P., Pappas, I. O., \& Kostagiolas, P. (2017). Explaining travellers online information satisfaction: A complexity theory approach on information needs, barriers, sources and personal characteristics. Information \& Management, 54(6), 814-824. https://doi.org/10.1016/j.im.2017.03.004

Kraus, S., Ribeiro-Soriano, D., \& Schüssler, M. (2018). Fuzzy-set qualitative comparative analysis (fsQCA) in entrepreneurship and innovation research-the rise of a method. International Entrepreneurship and Management Journal, 14(1), 15-33. https://doi.org/10.1007/s11365-017-0461-8 
Lampropoulos, G., Siakas, K., \& Anastasiadis, T. (2019). Internet of things in the context of industry 4.0: An overview. International Journal of Entrepreneurial Knowledge, 7(1), 4-19. https://doi.org/10.2478/ijek-2019-0001

Liu, Y., Mezei, J., Kostakos, V., \& Li, H. (2017). Applying configurational analysis to IS behavioural research: a methodological alternative for modelling combinatorial complexities. Information Systems Journal, 27(1), 59-89. https://doi.org/10.1111/isj.12094

Mariano, E. B., Gobbo Jr., J. A., Camioto, F. D. C., \& Rebelatto, D. A. D. N. (2017). CO2 emissions and logistics performance: a composite index proposal. Journal of Cleaner Production, 163, 166-178. https://doi.org/10.1016/j.jclepro.2016.05.084

Martí, L., Puertas, R., \& García, L. (2014). The importance of the Logistics Performance Index in international trade. Applied Economics, 46(24), 2982-2992. https://doi.org/10.1080/00036846.2014.916394

Milenković, N., Kalaš, B., Mirović, V., \& Andrašić, J. (2020). The impact of macroeconomic determinants and tax form on inflation in selected Balkan countries. Serbian Journal of Management, 15(1), 7-18. https://doi.org/10.5937/sjm15-16685

Mladenović, S. S., Mladenović, I., \& Ćuzović, D. (2019). Distributive trade and economic growth: EU28 evidence for the period 2008-2015. Journal of Business Economics and Management, 20(3), 489-506. https://doi.org/10.3846/jbem.2019.9857

Morris, R., \& Aziz, A. (2011). Ease of doing business and FDI inflow to Sub-Saharan Africa and Asian countries. Cross Cultural Management: An International Journal, 18(4), 400-411. https://doi.org/10.1108/13527601111179483

Naudé, W. (2010). Entrepreneurship, developing countries, and development economics: New approaches and insights. Small Business Economics, 34, 1-12. https://doi.org/10.1007/s11187-009-9198-2

Pinheiro-Alves, R., \& Zambujal-Oliveira, J. (2012). The Ease of Doing Business Index as a tool for investment location decisions. Economics Letters, 117(1), 66-70.

https://doi.org/10.1016/j.econlet.2012.04.026

Ragin, C. C. (2000). Fuzzy-set social science. University of Chicago Press. https://doi.org/10.1017/S0022381607080309

Rantasila, K., \& Ojala, L. (2015). National-level logistics costs: An overview of extant research. International Journal of Logistics Research and Applications, 18(4), 313-324. https://doi.org/10.1080/13675567.2015.1016413

Rogge, N., \& Archer, G. (2021). Measuring and analyzing country change in establishing ease of doing business using a revised version of World Bank's Ease of Doing Business Index. European Journal of Operational Research, 290(1), 373-385. https://doi.org/10.1016/j.ejor.2020.07.065

Ruzekova, V., Kittova, Z., \& Steinhauser, D. (2020). Export performance as a measurement of competitiveness. Journal of Competitiveness, 12(1), 145-160. https://doi.org/10.7441/joc.2020.01.09

Schneider, M. R., Schulze-Bentrop, C., \& Paunescu, M. (2010). Mapping the institutional capital of high-tech firms: A fuzzy-set analysis of capitalist variety and export performance. Journal of International Business Studies, 41(2), 246-266. https://doi.org/10.1057/jibs.2009.36

Skarmeas, D., Leonidou, C. N., \& Saridakis, C. (2014). Examining the role of CSR skepticism using fuzzy-set qualitative comparative analysis. Journal of Business Research, 67(9), 1796-1805. https://doi.org/10.1016/j.jbusres.2013.12.010

Solakivi, T., Ojala, L., Töyli, J., Hälinen, H.-M., Lorentz, H., Rantasila, K., \& Naula, T. (2009). Finland State of Logistics 2009. Ministry of Transport and Communications Finland, Helsinki. Retrieved August 18, 2020, from https://trid.trb.org/view.aspx?id=907192

Sriyana, J., \& Afandi, A. (2020). Asymmetric effects of trade openness on economic growth in selected ASEAN countries. E\&M Economics and Management, 23(2), 66-82.

https://doi.org/10.15240/tul/001/2020-2-005 
Su, S., \& Ke, J. (2017). National logistics performance benchmarking: A process-based approach using World Bank Logistics Performance Index database. Journal of Supply Chain and Operations Management, 15(1), 55-78.

Tvaronavičienè, M., \& Ginevičius, R. (2003) Analysis of foreign direct investments and its impact on restructuring of Lithuanian economy. Journal of Business Economics and Management, 4(3), 184-197. https://doi.org/10.3846/16111699.2003.9636053

Virglerová, Z., Conte, F., Amoah, J., \& Massaro, M. R. (2020). The perception of legal risk and its impact on the business of SMEs. International Journal of Enterpreneurial Knowledge, 8(2), 1-13. https://doi.org/10.37335/ijek.v8i2.115

Wang, C., Kim, Y. S., \& Kim, C. Y. (2021). Causality between logistics infrastructure and economic development in China. Transport Policy, 100, 49-58. https://doi.org/10.1016/j.tranpol.2020.10.005

Woodside, A. G. (2013). Moving beyond multiple regression analysis to algorithms: Calling for adoption of a paradigm shift from symmetric to asymmetric thinking in data analysis and crafting theory. Journal of Business Research, 66(4), 463-472. https://doi.org/10.1016/j.jbusres.2012.12.021

World Bank. (2014). The LPI Methodology. Retrieved October 17, 2020, from https://wb-lpi-media. s3.amazonaws.com/LPI\%20Methodology.pdf

World Bank. (2018). Logistics performance Index. Retrieved February 9, 2021, from https://lpi.worldbank.org/

World Bank. (2019). Doing Business Indicators. Retrieved September 15, 2020, from https://databank. worldbank.org/source/doing-business

World Bank. (2020). Doing Business 2020. Retrieved November 11, 2020, from https://openknowledge. worldbank.org/bitstream/handle/10986/32436/9781464814402.pdf 